Fecha de recepción: marzo 2020 Fecha de aceptación: abril 2020 Versión final: junio 2020

\section{De la deconstrucción y reinterpretación del sujeto heroico: el ocaso del héroe patriarcal y el advenimiento de la heroína. Una visión holística, complementaria e inter esencial de la heroicidad humana}

Tomás Stiegwardt ${ }^{(1)}$ y Gabriel Los Santos ${ }^{(2)}$

Resumen: La idea de heroicidad y su valor como símbolo ha sido central en muchas culturas. Fue la narrativa en sus diversos modos la que la ha consagrado en una miríada de historias, mitos y leyendas. Desde los cuentos orales hasta la actual concepción transmedial. Pero si en todo el mundo se encuentran historias de héroes, ha sido en Occidente donde en la necesidad de su creación y expansión, han germinado innumerables versiones de héroes cuyas acciones y hazañas han construido el imaginario de nuestra civilización.

Heroicidad es un valor fundante de la forma de pensar, sentir, comprender el mundo y a sí mismo en la cultura. Y su marca más reconocible es el individualismo.

La autopercepción del ser occidental se estructura alrededor de salvadores y enviados que hacen la diferencia para todos. Y tiene un signo, el sello del pensamiento dominante asentado sobre una premisa indiscutible: Dios es varón. Tiene barba, es fuerte, omnipotente y enojón. Crea y castiga. Y ese modelo axiomático fue injertado en el ideal del héroe. Sus características básicas son fuerza, determinación, coraje, valentía, arrojo y de vez en cuando, inteligencia.

No es extraño que su versión humana, con fallos y desaciertos pero divinizada por sus acciones sea, en una abrumadora mayoría de casos, un hombre. El héroe que ha sido propuesto por el pensamiento es casi siempre, un varón.

Ser un héroe -y ser reconocido como tal- ha sido y es una meta en sí misma, un punto de llegada, un título, una razón de ser. Tanto así para el individuo como para la sociedad que lo produce o adopta, contiene y promueve. El héroe resuena en la mente del pueblo, en su imaginario y como consecuencia de ello queda inscrito en la historia. El héroe inmortaliza un fragmento de su existencia y con ello un humano vulgar y corriente se transforma por sus acciones en un integrante de una selecta casta. Se hace en cierto modo, divino.

Como consecuencia han quedado al margen (casi en la clandestinidad cultural) valores como la capacidad de escucha, la empatía, ternura, interacción dinámica y cuidado de la naturaleza y de los otros que son generalmente atribuidos a la mujer, y éstos valores, que se asientan en la vida más que en la muerte no ofrecen en nuestra sociedad, la noción de heroicidad.

En los últimos años (y por el cambio de paradigma respecto al rol de la mujer y por una muy concreta demanda del mercado) el cine y la televisión nos han arrojado una varie- 
dad de mujeres de carácter heroico. Sin embargo, cuanto más se intenta la unificación del rol bajo diversas fórmulas, más se cae -salvo contadas excepciones- en la tentación de construir heroínas desprovistas de esencia, copias burdas del varón.

Una forma de heroicidad femenina habrá de socavar las zonas más oscuras del modelo político de la sociedad occidental: el concepto patriarcal, ya que allí se encuentra el sesgo. En la construcción de una heroicidad femenina habrá un contrasentido implícito con las nociones preexistentes de heroicidad dado que entre crear, nutrir y cuidar o salir al mundo a degollar enemigos, hay un abismo conceptual.

Una forma heroica femenina tal vez concluya en que ni siquiera ha de denominarse de esa forma. Al menos que también se resignifique el concepto de héroe. El advenimiento de la heroína podría crear una paradoja semántica. Quizás su efectiva realización consista en deshacer por completo la idea de que lo heroico es necesario es inefable y natural. Quizás su mera enunciación pueda generar una brecha disruptiva en el sistema y éste sea en sí mismo, un acto de heroicidad femenina.

Palabras clave: Heroicidad - transmedial - patriarcado - femenino - axioma.

[Resúmenes en inglés y portugués en las páginas 49-52]

(1) Tomás Stiegwardt es ilustrador, cineasta, guionista y académico. Licenciado en Diseño (UP), Profesor egresado de la Escuela Nacional de Bellas Artes y Realizador de Cine y TV de la Escuela Superior de Cinematografía. Gana las becas Subiela, Ibermedia y UP. Obtiene numerosos premios de guión y dirección y gana el Fondo Nacional de las Artes 2018. Su proyecto Diablillos Estelares es premiado en Expotoons por el Gobierno de la Ciudad y es invitado por Dreamworks. Diserta sobre cine y creatividad en la Columbia College de Chicago y la University of Illinois (UC, USA). Escribe papers sobre creatividad y arte. Tomas enseña realización de cine, guión y producción en la Universidad de Palermo.

(2) Gabriel Los Santos es académico, dramaturgo y cineasta. Licenciado en Enseñanza de las Artes Audiovisuales (UNSAM) y Puesta en Escena (EMAD). Estrena obras de teatro en España y Argentina. Gana: Proteatro, Fondo Nacional de las Artes. Creador del Método de Actuación "Movilidad Energética”, organiza el Encuentro Internacional de entrenamiento actoral auspiciado por el Ayuntamiento de Aragón (España). Obtiene premios en Cuba y Argentina. Expone su material audiovisual en la Columbia College de Chicago y la University of Illinois (UC, USA) Enseña Cine y Pedagogía del Diseño. En la Universidad de Palermo Gabriel es Director del Área Audiovisual de la Facultad de Diseño y Comunicación. 
Mientras se están terminando los últimos retoques a estos manuscritos luego de un año de trabajo intenso y colaborativo llegan a la mesa, raudales de noticias de todo el mundo, en una andanada casi imparable de sucesos caóticos de toda índole. El mundo ha colapsado. De verdad. No es una metáfora. La realidad se ha impuesto una vez, a las más osadas fantasías literarias.

El mundo en estos momentos está en cuarentena por el Covid-19, las economías globales se arrastran hacia un previsible caos y existe una concreta incertidumbre sobre el futuro en cada habitante del planeta.

$\mathrm{Y}$ en medio de este mar agitado se cierne sobre la sociedad el desafío de comprender su entorno, y de ser posible, trascenderlo.

El trabajo aquí presentado se cierne específicamente sobre los tópicos de la heroicidad femenina y este tópico podría parecer no estar vinculado a lo anterior, pero lo está y mucho. El primer sesgo de interpretación sobre la realidad es la creencia de que ésta es objetiva, real, única y traslúcida. No lo es. Nunca lo fue.

Con independencia del nombre del virus que en la actualidad está azotando a la humanidad (es previsible que habrá un Covid-20, 21 y otras tantas pandemias en el futuro), lo cierto es que se trata solo de uno más de los innumerables problemas, situaciones y tragedias que se viven en este momento particular de la historia. Vivimos frente al desmembramiento de los núcleos de pensamiento conocidos y es por ello que incluso la ciencia ha demostrado estar varios pasos atrás de los eventos que propone a modo de desafío la naturaleza. Justo cuando los movimientos feministas, los colectivos de la diversidad y la igualdad habían alcanzado los oídos del sistema político, la mass media y el mundo del entretenimiento.

Los sucesos que desembocaron en junio de 2020 en los Estados Unidos en manifestaciones colectivas gigantes, y como consecuencia de ello la declaración de estado de sitio en Minnesota, Nueva York y varios otros estados a consecuencia de la muerte de George Floyd ahogado con la rodilla por ocho minutos por un oficial de la policía supera algunos trazos de la ficción más salvaje. En este mismo instante, en Argentina, y a mitad de una pandemia mundial, un fiscal deja libres a un grupo entero de varones que habían violado a una joven de dieciséis años por considerarlo un acto de "desahogo sexual". Esto se da en medio de un mundo que convulsiona. Que tambalea y se precipita hacia la el caos de la impotencia y la tentación de las soluciones fáciles (coacción, represión, sometimiento, renunciamiento a la libertad) en aras de volver a poner "la casa en orden". Pero es exactamente este el punto nodal que ha de revisarse con urgencia: la idea de normalidad. Como dijo la filósofa canadiense Naomi Klein en un artículo reciente:

"Cuando la gente habla sobre cuándo las cosas volverán a la normalidad, debemos recordar que la normalidad era la crisis."

Ni siquiera se tratará en este breve ensayo de los otros miles de problemas a nivel mundial: guerras, tráfico de órganos, secuestros, empobrecimiento programado y centralización del poder y dentro de esto, la violencia de género, la persecución política de cualquier signo y en todo el globo no son ni aislados ni raros. 
Pues todo este pandemónium, este desastre pre apocalíptico en todas sus variantes y el corte entre el individuo, la sociedad y la naturaleza, tiene un signo inequívoco: vivimos dentro de la realidad creada por un sistema patriarcal. Este sistema desestima los valores que no le son afines, tales como la equidad, la distribución, la vida comunitaria, lo nutricio, aquello que cobija, hacer madurar, crecer, compartir, vincular y en general todo aquello que no sea la extracción, imposición y destrucción a cambio de algún tipo de obtención de poder.

Es que ahora, más que nunca y quizás como única esperanza de revertir -de ser esto posible- la tendencia entrópica a la destrucción y rotura de todos los sistema y vínculos con la vida, que se requiere de una interacción en donde vida y humano, vayan de la mano con la fuente real de la posibilidad de la vita: la naturaleza.

Como dice la antropóloga Rita Segato en su libro Contrapedagogías de la crueldad:

"El paradigma de explotación actual supone una variedad enorme de formas de desprotección y precariedad de la vida, y esta modalidad de explotación depende de un principio de crueldad consistente en la disminución de la empatía de los sujetos."

Este es el camino de la heroína, de las heroínas, de los sujetos heroicos (sean éstos hombres, mujeres, trans, o cualquier denominación presente o futura): la reconstrucción de una identidad humana y natural que permite tanto evitar la extinción como su otra opción (propuesta por vía indirecta por un sistema que no quiere perder sus privilegios) que es la de una elite que decide, domina y esclaviza a una gran mayoría de la humanidad. El camino de la heroicidad femenina es en primer lugar una apuesta a la vida.

Esta introducción poco ortodoxa y casi a quemarropa intenta poner un grito de alto en el entramado de acciones mecánicas que el sistema precisa para seguir con vida. El pensamiento crítico tiene entre tantas funciones, la ocupación de poner la lupa o el telescopio, el foco y o el gran angular de la cámara mental, en los lugares e intersticios de las zonas fantasmáticas de la sociedad y la cultura. A contrapelo de la tan ansiada erudición enciclopedista y de la precisión de rayo láser para la indagación y análisis de un punto en particular de la totalidad, se propone una mirada en verdad holográfica, abarcativa, multidisciplinar, incluso con posibles contrasentidos ya que la vida en todas sus manifestaciones es el resultado de las interdependencias, de la vincularidad y la multiplicidad. Estos son tiempos normales (si acaso alguna vez lo fueron) y desde este lugar es que se propone cavar hondo en el magma social y su pensamiento. Los ejemplos presentados buscan ser tan variados como en apariencia, desconectados como lo están la nuez de un rayo, el átomo de un sentimiento o una idea del magnetismo terrestre. Todo está unido, todos somos una misma unidad funcionando en sincronía.

Es fundamental entender desde todos los ámbitos del pensamiento que este tipo de pronunciaciones no son metafóricas ni poéticas.

Dice Mendel Sachs:

"La verdadera revolución que trajo la teoría de Einstein fue el abandono de la idea de que el sistema de coordenadas de espacio y tiempo tenía un significado 
objetivo como entidad física independiente. En lugar de esa idea, la teoría de la relatividad nos dice que las coordenadas de espacio y tiempo son solo los elementos de un lenguaje, que es utilizado por un observador para describir su medio ambiente."

Cuando hablamos del Camino de la Heroína desde estos ensayos lo hacemos dentro del campo de acción que nos convoca que es el de la narrativa en cualquiera de sus aristas, sean el cine, la televisión, las series, el cómic o cualquier formato que despliegue una idea narrativa

Pero como se dijo inicialmente, la narrativa implica el uso del lenguaje y como dijo Lacan "El inconsciente se estructura como un lenguaje" y esto es tan cierto que todo discurso está construido en base al uso semantizado de determinada manera de las palabras. Éstas son lo que expresan en forma específica pero también lo que connotan, lo que infieren, implican, desencadenan, inducen y a lo que refieren en forma directa pero también hiperbólica.

Como un boomerang conceptual las palabras vuelven a su propia usina de formación y ésta se encuentra cristalizando desde hace milenios una formación cuyo centro, eje, núcleo y emanación "divina" gira alrededor de las premisas incuestionables con calificación de anatema, de un pensamiento de supremacía patriarcal, porque como se expuso con anterioridad su nudo central, el centro atómico alrededor del cual giran todos los otros conceptos, ideas, creencias, sueños y mandatos.

Es la idea de un dios varón, macho, violento o dado a los perdones según su propio y particular arbitrio, ambicioso, omnipresente, inmortal, vengativo y cruel. Ese dios no es un dios femenino. No nutre ni cobija, no contiene ni llora.

En algunos otros sistemas de creencias antiguos o actuales existen otras formas de equilibrio en el que a cada dios de aspecto masculino se le opone uno femenino y esto hace o logra alguna forma de equilibrio que dinamiza los procesos naturales de la vida. La diosa Kali es una diosa de la muerte y puede ser cruel (como lo es una parte de la pisque humana) pero no es de ninguna manera la única ni la principal. Vive en una balanza permanente que cicla la alternancia de las fuerzas de la naturaleza visible o invisible y con ello el juego de la vida continúa con sus variantes y alternancias.

La naturalización con la que Occidente se ha rendido a una idea única de representación iconográfica de la deidad es llamativa por su simpleza. De los millones de posibilidades gráficas potenciales en el imaginario basado en cualquier tipo de forma biológica o abstracta se ha elegido a un señor de barba. Un señor mayor, con cara adusta, de contextura fuerte y mirada enérgica que desde el cielo (un lugar que existe en el "arriba" conceptual del imaginario) manda, ordena y favorece la conquista, el sometimiento, la violencia y que castiga por siempre en todos los infiernos concebidos, no solo a pecadores sino a incrédulos, apóstatas, blasfemos y a todo ser que no se encuentre en el círculo de elecciones esbozado junto a la pintura de su propio rostro.

Así las mujeres son seres de segunda clase nacidas de una costilla de otro hombre llamado Adán. Pero la mitología no se detiene ahí. Eva no fue siquiera la primera mujer del buen Adán sino que fue una tal Lilith. Pero esta mujer (fuerza femenina desatada y fuera del control que este dios había previsto para su existencia) no era lo suficientemente sumisa para ser parte de ese paraíso creado. Y Dios la desterró. La mandó al olvido y al oprobio. 
Lilith pasó entonces a representar todo lo no deseable en una fémina. Rebelión, contradicciones, emocionalidad fulgurante, intento de paridad y en especial sensualidad. Todo aquello que no se quería para esta tierra creada. Pasó entonces al ostracismo conceptual y a las espesuras del olvido. De hecho muchos lectores podrían sorprenderse pensando que lo aquí narrado es un invento o una ficción de leyenda fantasiosa de la ficción. Y lo es si se toma como ficción las Sagradas Escrituras.

La idea de heroicidad es intrínseca al pensamiento de Occidente mucho más allá de lo que los mitos y leyendas dejan entrever.

Hunde sus raíces en una visión del futuro a la medida de las ambiciones y necesidades, un modo de entender la vida y el mecanismo social y una forma de concebir la existencia. Extrae sus atributos de un modelo que, aunque no necesariamente consciente y deliberado en su origen, ciñe su ethos en su indiscutible vocación evangelizadora y en la propagación de una doctrina que con todas sus variantes parte de una idea única, cuyas premisas no han de discutirse. La principal, la que todo lo modela y moldea es que Dios es varón. Y esta idea es más política que religiosa. O puesto de otro modo su concepción está politizada como causa y se manifiesta como doctrina y acción en el mundo real.

La sociedad ha fabricado héroes de todo tipo, forma, carácter y estilo. Se ha forjado desde la antigüedad una cierta tipología de "sujetos heroicos" que sin parecerse en lo aparente, confluyen y distribuyen una cantidad más o menos detectable de conductas y creencias, actitudes y racionalizaciones y en definitiva, catalizan las ambiciones y el saber de una cultura que, siendo en extremo expansionista, regula las secreciones narrativas y artísticas al punto de convertirlas en la expresión de su interés primordial.

El varón ha sido así en extremo útil para satisfacer esa necesidad de accionar debido a su naturaleza socializada según el modelo patriarcal, en donde los atributos de un "hombre" han de contener de una u otra forma algún grado de violencia, deshumanización y falta de empatía y por lo tanto, un desinterés en la vida ajena en la medida que esté del otro lado de la demarcación cultural. En un equilibrio ideal, éste se hubiese moderado y aún reenfocado con la natural cercanía que tiene la mujer en cuanto dadora de vida. Sin embargo esto no le era funcional a la necesidad de idealizar ciertas conductas que, vistas de una perspectiva más amplia serían al menos, dignas de discusión de análisis crítico. Y no es difícil en nuestra cultura occidental imaginar a Dios. Lo han descrito en la biblia, lo han pintado a través de los tiempos y su retrato quizás más famoso es ya un logotipo dentro de la iconografía de la cristiandad. Nos referimos pues a los murales de las bóvedas de la Capilla Sixtina. En ella Dios en persona (como se ha dicho con barba y musculado) conecta a través de su dedo divino al hombre. Pero no necesariamente a la humanidad. Al hombre, el varón. Esta imagen no es inocente. Independientemente de su genialidad pictórica y de las sin duda nobles intenciones artísticas de Michelangelo Buanarotti su carga significativa ha ejercido en el imaginario popular una idea que está tan insertada en la sociedad que es prácticamente indiscutible. Y no solo por los creyentes sino casi inconscientemente por cualquier persona. Incluso un ateo afirmará no creer en "ese señor de barba" o algún tipo de comentario semejante. Es que este dios monoteísta tiene barba, le gusta mandar y que le obedezcan. Castiga, humilla y vigila. Es iracundo e incluso violento. Dice amar y lo hace, siempre que ese amor sea jugado en sus términos, es decir los de la obediencia irrestricta. 
Fragmentar la percepción de la propia identidad del ser femenino ha sido parte de la poda conceptual que el pensamiento patriarcal ha ritualizado a través de la adulteración progresiva de la semántica del lenguaje.

El poder ha venido ejerciendo su presión a través de las sutilezas y matices del lenguaje. Es por ello la importancia de la deconstrucción de un discurso que está viciado de origen. Porque a la trama ya compleja de la vida, se le ha adosado un condicionante interpretativo que sesga y anula cualquier variación o confrontación. Cuando a través de un texto de índole investigativa, académica o de circulación cultural se profundiza y debate una idea en particular, no solo se trata de un mero juego intelectual sino en esencia, de una reformulación de su contenido que busca corregir las desigualdades que lleva implícita una creencia en particular. En este caso y en forma muy concreta, la de la dominación necesaria de la mujer por parte del varón.

La consolidación de ideas patriarcales en el seno de las sociedades y de los individuos, es a tal punto que, ha logrado que su ejercicio particular del poder pareciera corresponderse a algo natural. Las incisiones en la carnadura de la cultura, hechas a lo largo de la historia pero especialmente pregnantes en la segunda mitad del siglo XX y en el actual tiempo, han puesto el foco en todo aquello que es medible en términos de la economía.

Vivimos en la era de la especialización, del foco en el detalle, en el ojo del microscopio, en la nanotecnología y las terapias de células madre. La mirada se ha centrado a tal punto que por intermedio de la ciencia y del surgimiento de una cantidad de neologismos para designar objetos y procesos invisibles al ojo, la mente del humano se ha vuelto filosa como un bisturí y rigurosa en extremo. Cualquier profesional que pretenda triunfar e insertarse en el modelo económico más productivo, debe especializarse. Se sostiene que de esta manera se sabe más, se conoce en profundidad, se "va al hueso" y que esto debería generar una comprensión más profunda de los sucesos y procesos de los fenómenos abarcados. En parte es cierto. No hay duda que la mirada ajustada a un fenómeno en particular puede eventualmente lograr un conocimiento detallado de la cosa. Sin embargo cuanto más se observa el detalle, más se pierde el conjunto. $\mathrm{O}$ en todo caso, menos se logra la comprensión del contexto en que lo estudiado actúa, se mueve o participa. La fisión nuclear, los campos gravitatorios de los electrones, los nanochips se han convertido en "el Dorado" de la ciencia y de su aplicación práctica en combustibles, celulares, medicina atómica o ingeniería cuántica. Así fue cuando a comienzos del siglo XX la teoría de la relatividad y sus posteriores avances en el campo de la fusión y fisión del átomo derivaron en la construcción de las bombas atómicas que destruyeron Hiroshima y Nagasaki. El ser humano se ve envuelto en capas de conocimiento que no puede acoplar a una realidad total de la existencia. Pasa incluso lo mismo en el campo académico y en los ensayos, tesis y presentaciones ajustados, fenómenos estudiados con precisión extrema pero que difícilmente se conecten con el marco, contexto, campo y mundo que los contiene. Y es justamente este, otro sesgo patriarcal. La idea de la precisión es netamente una obra de ingeniería intelectual de corte masculina, en especial si ésta cumple algún propósito armamentístico, un producto vendible o una idea contagiable. El recorte temático tan anhelado y promovido a veces incluso desde las universidades y centros de investigación logra justeza en el análisis pero dilapida recursos en el desmembramiento mientras le es en extremo difícil contextualizar aquello con el entretejido más amplio y holístico 
de la naturaleza. El pensamiento masculino tiende a ser secuencial, enfocado, dirigido, cortante y se encuentra amurallado del resto de otras ideas o conceptos. El pensamiento femenino en cambio contiene una multiplicidad de mundos que juegan a la par, a la vez observa y cataliza diversos elementos y procesos y los unifica bajo un mismo campo conceptual. De alguna manera, lo validado en los tiempos actuales y muy especialmente en la cultura de Occidente, está relacionado a un tipo de intelectualidad de corte masculino, ácido, cortante, independiente, incisivo, duro. Quedan entonces al margen los atributos de la complementariedad donde la interrelación, la dinámica múltiple, la interdependencia y el sentido comunitario tienen su máxima expresión, es decir, en el pensamiento femenino. El héroe tradicional tiene un objetivo. Uno solo. Va de A a B. Navega, viaja, camina o vuela entre una diversidad de pruebas y batallas con el único objetivo de alcanzar una meta, exactamente como lo hace el espermatozoide. Esto es parte de la existencia material en el universo. Aun así la vida se compone de al menos dos partes y es esta otra parte la que difícilmente encuentra su lugar en la narrativa y por lo tanto en la figura o el pensamiento heroico. El óvulo atrae, protege, elige, nutre, hace crecer y en todo ese proceso se forma la vida. El camino heroico del espermatozoide consiste en llegar a penetrar el óvulo y el del óvulo en hacer nacer la vida. Es quizás por ello que la mujer tiene por naturaleza un sentido gregario mayor, una consciencia comunitaria más desarrollada y puede de esta manera, concebir la vida como una relación interdependiente entre los miles de aspectos que la rodean.

Por ello la tentación de encontrar "la fórmula", el esquema, el método o la indicación precisa sobre como podría ser el Camino de la Heroína es en sí una trampa, un salto sin red en los espacios de la teoría en donde todo es construible pero no por ello apropiado. No se trata tampoco de que no se pueda buscar una forma de sistematizar un concepto relacionado con este punto sino el hecho singular de que el concepto mismo pueda ser reconsiderado como algo múltiple en lugar de único y acabado. Como sucede con el holograma en donde puede verse una figura que no existe desde cualquier ángulo o como el ADN genético donde a partir de una célula se puede recrear un ser vivo. Algo así sucede con el complejo mundo de las emociones, los sentimientos y las percepciones. No hay una sola interpretación ni una sola lectura sobre un mismo fenómeno como un llanto, una sonrisa, un estallido de rabia o la visualización de una idea que aún no tiene forma. Este campo (el emocional) remite a uno de los mayores miedos en el terreno del pensamiento de corte patriarcal. "Vaya al grano" es una frase habitual tanto en el campo académico, económico o hasta en las relaciones humanas. Justamente es ese nivel de concentración el que impide ver lo más simple: el grano contiene vida, la vida requiere tierra, nutriente, agua, sol, cuidado, la vida que contiene el grano ha de crecer, estar expuesta a las inclemencias del tiempo, del espacio, de los predadores, parásitos y con suerte, hacia el final del proceso de germinación se obtendrá una planta que a su vez dará flores, hojas, frutos y nuevas semillas. Esa planta podrá nutrir o matar y será parte de la estructura corporal de un ser humano, una hormiga o una rata que a su vez será parte de una infinita cadena de circunstancias, sucesos, momentos y a la vez generará otras infinitas posibilidades. Eso es la vida y cuando el pensamiento en su afán de horadar el misterio mínimo, pierde esta visión, se vuelve frío, acaso violento, cortante y fragmentado. Exactamente como impulsa la visión patriarcal: una mirada circunscripta y descontextualizada en donde el 
todo y la parte no tienen un vínculo dinámico sino que se ven encontrados como enemigos conceptuales. Forma y fondo, Marco y obra, Sujeto y objeto. Antagonismos que no son necesarios como enemigos pero si, fundamentales como complemento, uno no puede existir sin el otro. Lo que los orientales han llamado el yin y el yang.

Una buena parte de los problemas del mundo, desde la deforestación hasta el fracking en la minería, la extracción de minerales, petróleo y gas con la consecuente destrucción del entorno, los cultivos transgénicos, la contaminación y polución, los virus imparables como el Covid-19, las enfermedades endémicas como el zica, dengue o malaria y un sinnúmero de otras calamidades se presentan en relación de causa y efecto con el entorno natural. Y este vínculo, por demás obvio pero desestimado es un campo en el que ningún héroe tiene poder. En la película Avatar (James Cameron) se constituye una suerte de inteligencia natural en el planeta Pandora. Sus nativos, llamados los $\mathrm{Na}$-vi, viven en una comunión armónica con su entorno, una formación social de corte tribal en la que la anciana sabia es quien resguarda el vínculo con el mundo natural y es ella (una mujer) quien indica los caminos, bendice las uniones y tanto lee lo mejor para todos como lo comparte. En esta historia hay grandes guerreros (hombres y mujeres) pero en última instancia están sujetos a la sabiduría y contacto que tiene la anciana. De eso se trata: de la vincularidad. El peso específico del elemento que conecta o el mismo sentido de la conexión tiene tanto o más valor que el sujeto por más heroicas que sean sus acciones. En la física cuántica se ha establecido que las redes de conexión son en sí mismas un poder inteligente y que cuando éstas se alteran, sus partes sufren pérdidas, se desintegran o enferman, y esto es frecuente en las células de los cuerpos, La conexión dada por los lazos (biofotones) son en sí mismos una unidad y ésta se comporta sincrónicamente, es decir, en armonía.

Una heroicidad femenina es también su politicidad. Como dice Hannah Arendt:

"Nadie puede ser feliz sin participar en la felicidad pública, nadie puede ser libre sin la experiencia de la libertad pública, y nadie, finalmente, puede ser feliz o libre sin implicarse y formar parte del poder político."

Desterrar siquiera el interés de las mujeres a lo largo de la historia cuando no directamente segregarlas de ella como sujeto político ha sido parte de la fundación imperial del gobierno del varón. Todo aquello que no es decidido es concedido y en este sentido la mitad de la humanidad fue relegada a un lugar de servidumbre conceptual de la otra. Sin siquiera entrar en los otros sometimientos de tipo racial, étnico y geopolítico en donde la figura mandante ha construido su base y su trono.

Porque si a alguien se le pasó el detalle, este dios es además indiscutiblemente blanco.

En el farragoso universo de las opiniones, el núcleo simbólico de una buena parte del pensamiento occidental se ha centrado reiteradamente en la función utilitaria y esto es particularmente relevante en los relatos y en su costado persuasivo más notorio: el discurso.

Es que la opinión como elemento singular, se ha vuelto de manera circular en una porción analizable de la cultura, que por diversos motivos engendra un status quo diferente según el momento histórico y las necesidades sociales y psicológicas de los grupos humanos. 
Por ello es que la palabra "storytelling" se ha puesto de moda. Contar una historia, ser un narrador, conquistar las mentes a través de un cuento o una letra de una canción, la propaganda política para instalar presidentes o un comercial de yogur de apio. No es el "que", es el "como".

Si por endoso de las ideas se termina adquiriendo un objeto inútil a un precio ridículo en condiciones absurdas para un uso estrafalario, no es extraño que las ideas constituyan el tejido invisible que ata y forma lo que las personas llaman opinión. Es algo curioso y si no fuera trágico por sus implicancias sería incluso gracioso.

Una fuente de poder elabora un discurso y lo "customiza" a medida de quien sea el destinatario final de aquello, esto se empaqueta en forma de narración y se envía directo a las mentes de los posibles y deseados consumidores. Raro es que puedan sustraerse: ya está todo estudiado. Incluso el porcentaje de pregnancia del mensaje. Y por ello es que ha habido reparos de intelectuales, filósofos y hasta movimientos religiosos respecto a la inclemente tarea de las agencias de publicidad que ya más que publicitar productos se ha convertido en lavaderos de cabezas.

Pero como todo sistema dinámico, el ir y venir de las oleadas sociales de gustos, creencias, tópicos de interés, modas, costumbres, ideologías, sistemas políticos y temáticas hace que incluso aquello que está en venta dependerá de lo que una sociedad demande. Este no es un juego libre sino un entramado complejo de ideas que nunca queda claro si han nacido de la necesidad o si ésta fue creada.

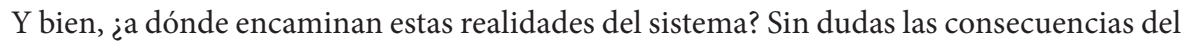
pensamiento unilateral esgrimido por el mercado de consumo sesgan las interpretaciones para adecuarlas a un pensamiento único. Cosa curiosa que las izquierdas y derechas del mundo sostengan con tanta pasión al fin y al cabo lo mismo: un pensamiento unificado. Discrepar es peligroso. Incluso en los ámbitos intelectuales y hasta de corte rebelde y rupturista. Pues en el dominio del pensamiento no ocurre otra cosa que en el ámbito del trabajo y es que los espacios conformados con preferencia son los del especialista. Campbell era acusado de poco incisivo por ser justamente un generalista, cosa que desagrada profundamente a los formadores de opinión cuya simiente es la cualidad de hacer irrumpir nuevos consumidores obedientes en el sistema. Y cuidado que consumo es todo, desde doctorados hasta pornografía, chicles o muebles de diseño, cultura del fitness, veganismo y new age. Independientemente de quien tenga la tan mentada razón en algún tema, todo será usado finalmente para ser colocado en un escaparate, una vidriera, un aviso o en el peor de los casos será troleado por sistemas bajo la bruma de la mente.

De los fantasmas que quedaron latentes de la guerra fría y de la antigua URSS, se han reconvertido en realidades de corte alegre, capitalista al extremo y de un ludismo apabullante. No hace falta más que pensar en los lavados de cerebro que se temían con las máquinas soviéticas y ahora hechas realidad por efecto de la publicidad, el marketing, las redes sociales y ciertos movimientos sociales de corte fanático. El miedo que se nos instalaba de los extremistas de varias regiones del mundo se han convertido en diseñadores de ideas unicistas como los encargados de la moda y la cultura popular.

En medio de esta tiranía oculta y jolgoriosa, se esconde lo que en el cine se ha dado en llamar un Eastern egg (huevo de pascuas) que es una sorpresa no obvia escondida en una escena o un lugar en un videojuego que pocos han logrado ver y menos aún lo 
comprenden. Se trata de los movimientos mundiales de mujeres. No las han visto venir. Porque en primer lugar se las desestimó como fuerza de cambio.

Es cierto que ya quieren ser captados dichos movimientos e instrumentalizados. El sistema no se pierde de nada. Todo lo usa, todo lo convierte en sí mismo como el afán de Mr. Smith en Matrix. La idea auto centrada y esencialmente narcisista de que todo sea un espejo de la proyección del sistema.

Los movimientos sociales de carácter inesperado, de orígenes múltiples, sin líderes, sin propósitos específicos, de corte transversal son esencialmente de arquitectura femenina. En cualquier movimiento de corte masculinizado, lo primero que se impone es un sistema piramidal, estructurado, rígido, con liderazgos fuertes. Uno o varios mandan, el resto sigue. Pero eso no es lo que está sucediendo. La fragmentación del proceso se revela como un antídoto suministrado previo al veneno. Tampoco es una garantía pero es algo. Y hoy día algo es mucho.

La delimitación de los espacios físicos, vitales, psicológicos y emocionales parecieran ser demarcados por este modelo reinante y omnipresente. Pues al fin y al cabo ¿Qué hay más omnipresente que Dios? Y Dios, en nuestra cultura, como se señaló antes, es varón. Es un macho dominante, y se parece mucho a lo que los biólogos han llamado predador ápex. En ciencias naturales (biología, zoología, ecología) y en antropología se denomina superpredador a los depredadores que no tienen depredadores naturales, situándose en lo alto de su cadena alimentaria.

La conquista y el triunfo (tanto de territorios físicos como de la colonización ideológica, religiosa y moral de las mentes) se corresponde a la faz moralizante de su accionar. Cualquier individuo, es a su vez portador y transmisor de esta idea de divinidad aunque no lo sepa ni le importe, incluso aunque se oponga. Pues en nuestra cultura de Occidente no ha sobrevivido en forma dominante una contraparte de faz femenina. La tenían algunos pueblos antiguos, en general politeístas o adoradores de algún aspecto de las fuerzas naturales. En la diversidad había toda clase de dioses y diosas. Más aún en las tierras hoy llamadas América en donde la noción de la Pacha Mama es connatural a la existencia misma de la vida anímica y cultural de los pueblos nativos. En las culturas prehispánicas la idea de una "tierra madre" se consideraba natural y la misma idea de fecundidad, crecimiento, contención, nutrición y cobijo establecía una relación natural de identificación con principios femeninos que incluían alguna forma de maternización, cuidado colectivo, crecimiento sustentable y criado comunitario. Las ideas hoy tan en boga acerca de la sustentabilidad en materia agrícola ganadera, las energías renovables, "verdes", de bajo impacto ambiental, reutilización y reciclado era parte intrínseca de la culturas prehispánicas.

Matar el símbolo es atacar la esencia de algo y toda cultura dominante, imperio o religión expansionista lo sabe muy bien. Matar los dioses de la tierra americana fue fundamental para la conquista de las tierras que los nativos poseían (o mejor dicho: en las cuales vivían) Pues al quebrar el espíritu simbólico de sus creencias, quebrantaron su razón de ser. Y como en la mayoría de estas culturas su forma de teología se vinculaba con fuerza a la naturaleza y sus manifestaciones, al matar el bisonte acabaron con su fuerza, al cazar sin "alma" a sus animales, les quitaron la esencia de lo sagrada de la caza ritual y al pisotear sus tierras y talar sus árboles resquebrajaron el sentimiento de pertenencia interdepen- 
diente de la tierra con lo humano. Podría pensarse que aquello era solo ambición de conquista y saña racial. Sin embargo los movimientos estaban bendecidos por todas las instituciones, iglesias y movimientos que formaban parte del entramado cultural que le dio fuerza, poder y especialmente libertad de acción a conquistadores, evangelizadores y pillos en general. En la cultura Guaraní de las tierras que hoy conforman parte de Brasil, Paraguay, Argentina y Uruguay se cometieron verdaderos horrores en aras de la religión (a los nativos los cocían de espaldas para que no escaparan, le cortaban los dedos de los pies y eran sometidos a toda clase de vejaciones que eran hechas "a la vista de dios" y con anuencia de las autoridades). Fueron matadas por hordas organizadas por los gobiernos centrales diversas tribus aborígenes desde el sur al norte.

Y esto, una vez más no es casual. La religión de los dioses de Occidente son varones (al menos en las religiones dominantes monoteístas) y Dios (que es hombre) exige sumisión, obediencia ciega, placer a gusto y ser atendido por sus "siervos".

No muy distinto de muchas de las relaciones de pareja heterosexual donde el hombre da por sentado que "así son las cosas" para dar por sentado que lavarán su ropa, preparán su comida, lo atenderán sexualmente y cuidarán de sus vástagos.

Dios (esta representación autocentrada en la imagen de un varón) entonces exige lealtad total y promete amor, siempre y cuando se cumplan con sus pedidos (que por supuesto son intermediadas por los administradores de la ley divina), y si ello no ocurre, este dios castiga con plagas, excomuniones, infiernos interminables y cuando eso no alcanza, envía a sus soldados a mutilar, masacrar o esclavizar a los reticentes.

Sin embargo con el advenimiento de la religión dominante se establecieron los parámetros para una ruptura entre los vínculos de convivencia basados en cierto equilibrio entre individuos y la naturaleza. Y no es ni casual ni puramente anecdótico que dicha imposición religiosa ha sido por la fuerza. Es que el monoteísmo de cultura patriarcal es por naturaleza violento. No solo por las exigencias de su legado evangelizador sino por su unilateralidad y falta de oposición. En culturas dualistas o de deidades múltiples, se establecía un equilibrio dinámico e incluso si hubiera un "dios dominante", éste no podía hacer lo que se le antojara pues el equilibrio lo ponía el resto de diosas y dioses o por último, el reglamento establecido como funcionamiento del universo. Ni el poderoso Odin de indiscutible poder y "padre de todo" osaba a veces enfrentar la furia de su esposa Hera y ésta en más de una ocasión lo conminó a cambios en sus pareceres y órdenes.

Pero el monoteísmo tiene una premisa insoslayable y es, la perfección absoluta, la omnisciencia, la palabra irrefutable, la eternidad absoluta y la sabiduría divina. Esos atributos le han caído como herencia al hombre (al varón) y en consecuencia su máxima aspiración filosófica es convertirse en un émulo de este dios. Si la idea de sacerdotes y religiosos es aspirar a una cierta clase de perfección que alcance la gracia del dios patriarcal, han sido los héroes los que llevan la carga y el poder de hacerse con alguno (nunca todos) de los atributos divinos y con ellos luchar en beneficio de unos y perjuicio de otros.

La idea de héroe acarrea una carga simbólica desde su nacimiento y es la superioridad del varón. Esa idea es como huésped injertado desde y hacia la cultura.

Las banderas de la abnegación (con auto sacrificio incluidos) sostienen como pilares las columnas del sistema de valores de Occidente como bandera psicosocial y la entrega a una causa en favor de una sociedad determinada como insignia. 
Y para ello se ha construido un dispositivo conceptual basado en los atributos que la cultura anhela y promueve.

La personificación de los valores detentados por la sociedad recayó así pues en el héroe que no es otra cosa que una versión microscópica de una cierta forma de divinidad. Sus características son los históricamente atribuidos al varón y por lo tanto el héroe ha sido en su inmensa mayoría, un hombre.

Pero si para un individuo en particular el volverse un héroe ha sido motivo de búsquedas y epopeyas para trascender, para la sociedad que lo contiene representa más bien la necesidad de ser representados en un determinado contexto histórico. Esto no sería criticable salvo porque este concepto de lo heroico tiene, por lo general, las connotaciones de los atributos relacionados con el mundo masculino, o quizás, habría que decir: con la exigencia de masculinidad que el sistema patriarcal (que incluye mujeres) desdobla como ideal y premia con honores y riquezas.

En los territorios de la narrativa actual se está decidiendo el futuro del mundo. Ni más ni menos.

Al contrario de lo que podría suponerse, lo que conduce el modelado social (y por lo tanto individual), no han sido ni son los poderes que se evidencian por el uso de las armas y el poder económico sino que está signado y estructurados por el uso del discurso.

Es cierto, que para la formulación, propagación y asiento definitivo de una idea, se hace uso del poder antes mencionado, pero sin discurso, sin narrativa, el andamiaje de las diversas formas de conquista se desmorona.

Al final, es la mente de las personas la que ha de ser conquistada incluso para que acepte su forma violenta, impuesta por el uso de la fuerza. Y para ello las imágenes que ésta percibe quedan adscriptas a la palabra, las frases.

Es la semántica. Pues es en la interpretación (decodificación) del lenguaje que la semilla plantada (natural o artificialmente) crece y germina. Ni las armas ni la ciencia han podido -a pesar de su poder más que evidente- ir por encima de quienes ostentan el dominio de la palabra. Pues bien entonces, ¿qué expresan los diversos modelos que pugnan por conquistar el mundo (nuestro cerebro)?

Creer con ingenuidad que un sistema determinado, que funciona $-\mathrm{y}$ sirve a intereses concretos- por miles de años, va a dejar de emitir su pulso fundacional solo porque algunos elementos del conjunto social así lo deseen es riesgoso. Lo cierto es que al contrario, éste maximiza su poder recurriendo a cuanta fisura en el tejido social encuentre y para ello nada mejor que el uso del lenguaje

La heroicidad como valor anclado en el tablero de disparadores conceptuales en donde existe una idea altamente tóxica de lo que debe ser un varón promueve una escala de valoración cuyo sesgo central reside en la excepcionalidad del espécimen (el héroe único) que para serlo debe someterse a una construcción ideológica determinada. La heroicidad ha sido fundante en la cosmología occidental, en su autopercepción y su crecimiento. Y en particular (sino casi unilateralmente) lo ha sido a lo largo de milenios en su versión masculina.

Ser un héroe, convertirse en héroe -y ser reconocido como tal- ha sido y es una meta en sí misma, un punto de llegada, un título, una razón de ser.

El héroe resuena en la mente del pueblo, en su imaginario y como consecuencia de ello queda inscrito en la historia. El héroe inmortaliza un fragmento de su existencia y con 
ello un humano vulgar y corriente se transforma por sus acciones en un integrante de una selecta casta por encima incluso de los títulos nobiliarios pues entra para siempre en el panteón de la cultura popular.

Y es que no se puede ser héroe por herencia ni pretender ser coronado, ni imbuido en su carácter sin haberlo ganado por alguna de las vías que entronizan un héroe en el mundo social: la guerra, el deporte, la medicina, la ciencia o el arte entre otros.

Así, el núcleo fallido de estos intentos radica en la incomprensión del sentido político de estos términos, que adolece de independencia del modelo central (patriarcal) cuya matriz aún establece -cuando no corroe- los fundamentos del pensamiento y por lo tanto toda proyección cultural. En la formas del relato que se han usado y popularizado en los últimos milenios, existe, encriptado y codificado, un proyecto social. Más aún, se entretejen los hilos del poder y son quienes los manejan, los que han estructurado, formado y adornado, los ideales que hoy tomamos como propios.

Así el héroe está infectado (ha sido inoculado por la superestructura de pensamiento valorativa) con un sesgo que lo hace impermeable a los cambios. En su atribulado andar y mediante hazañas en especial físicas y de coraje, reniega -sin siquiera saberlo- de un universo entero de posibilidades existenciales.

No se trata de que las desestime o descalifique, niegue o deteste: no las ve, no las puede ver. Para ser héroe en los cánones que glorifican su accionar, se debe, por lo general, renunciar a ser completo. Solo la confrontación avala el heroísmo. Nadie ha sido nunca héroe en una historia mítica por haber abrazado, amado, nutrido, cuidado o acompañado a otro.

Se es héroes muy comúnmente más por asesinar, derrocar, someter o exiliar. ¿A quiénes? A los malos claro, aquellos que deben ser eliminados y para ello no hay límites.

¿Y quiénes son los malos? Los que pretenden dañar al sistema, corromperlo, cambiarlo o tomar una ventaja indebida de sus portales invisibles. Es decir, quienes no se integran pero a su vez buscan una ventaja, una ganancia de algún tipo.

Es por esto mismo, quizás la fascinación que ejercen los villanos y las villanas en la literatura, el comic o el cine. Es que no se someten a la cultura. Por más retorcidos, siniestros o despóticos o crueles que sean, los villanos contienen una semilla de libertad de pensamiento y acción que provoca admiración (incluso acompañado de repugnancia). Los Hannibal Lecter, Voldermort, Darth Vader, Sauron, Maléfica, la Reina del Hielo, Cruela Deville y tantas otras celebradas formas de la villanía son en cierto punto quienes liberan un sistema de los excesos de presión de la caldera cultural. A veces son pústulas, granos espantosos que todos acuerdan en que deben ser removidos, pero aun así, son la crema y el néctar esencial de toda historia. Si no fuera por ellos ¿contra quién lucharían los héroes?

Y allí está entonces el relato primordial de la antesala de la narrativa: en el que, para la existencia del héroe ser requiere de un villano y para que exista el villano es preciso que exista el sistema que lo construya, y para que el sistema lo construya debe haber un relato moralizante al que los villanos no adscriben o no pueden lograr insertarse y por fin, un gran vacío relleno con un discurso único. El de los malos y los buenos. En última instancia los buenos son los que se alinean con la divinidad consagrada, es decir el dios patriarcal. Este dios patriarcal, no solo es varón, es blanco y occidental. 
En la película Matrix III se puede ver el Arquitecto (una representación posmoderna de Dios) le dice al "elegido" (Neo, el hombre que deviene en Salvador) que él es el sexto elegido de una larga cadena de nacimientos y muertes de la humanidad. Es decir, el elegido, el libertador, "el que se escapa del sistema", ha sido creado por el mismo sistema que cree combatir, para poner orden en los eventuales desequilibrios que todo sistema vital presenta. Se trata, en definitiva, de un ajustador de la entropía. Un plomero cósmico de la gran maquinaria de la creación. Su simbolismo puede rastrearse en todas las religiones de occidente y no es casual que éstas se hayan atribuido ser objeto de su metáfora.

Sin embargo, y desde esta perspectiva de análisis fuera de los moldes paradigmáticos hipnotizantes, Neo no es en verdad la figura salvadora de esa historia. Parece serlo y actúa en consecuencia más el verdadero cambio, la esencia del sacrificio inicial ante lo incierto lo hace Trinity. Ella se mete en la matriz a luchar contra todas las posibilidades y tras una muerte segura y no para "destruir al sistema" sino para salvar a quien ella ama o cree que ama. Salvar por amor. Una entrega.

Maureen Murdock presentó un modelo alternativo al de Joseph Campbell. Una forma de esquematizar y sistematizar los avatares por los que la mujer habría de pasar en su propio viaje interior y exterior de crecimiento personal.

1. Alejamiento de lo femenino

2. Identificación con lo masculino y reunión de aliados

3. Las pruebas del camino: enfrentamiento con ogros y dragones

4. Encuentro con el tesoro del éxito

5. Despertar de los sentimientos de aridez espiritual: muerte

6. Iniciación y descenso a la diosa

7. Urgente anhelo de reconectar con lo femenino

8. Sanación de la ruptura madre-hija

9. Sanación de lo masculino herido

10. Integración de los masculino y lo femenino

Estos pasos no constituyen una fórmula como tampoco lo es el "viaje del héroe" de Campbell, más bien una muestra de que existen intentos serios por encaminar una búsqueda en algún sentido.

\section{La heroína canibalizada}

Es por ello que la resolución de la trama de GOT (Juego de Tronos) fue instintivamente mal recibida por la mayoría de sus fanáticos.

Jon no mata a Daenerys por amor ni por la verdad ni por ningún sentimiento, sino por deber. Un deber implantado, relativo, viscoso y en definitiva, destinado a mantener un sistema, el statu quo de ese mundo.

Daenerys podía, eventualmente, representar un peligro según la construcción psicológica que de ella hicieron los autores especialmente hacia el final, pero aun así su lugar en la historia comenzaba a tejer una heroicidad completamente divergente de todo lo 
conocido. Y eso produjo pánico. En los personajes, en los autores y en el compilador de significado que es el sistema patriarcal, que vio en ella una representación peligrosa -acaso letal- para su existencia. Al fin y al cabo, este final no figuraba ni siquiera en la obra de su autor original JRR Martin.

En tiempos de series y universos ficcionales que plantean y construyen pensamiento y relato, es oportuno señalar y en cierto sentido desenmascarar, un tipo de pensamiento arácnido, escondido y tóxico que se esconde aún dentro de productos culturales que se pretenden progresistas pero que se dejan infectar desde la raíz con prejuicios y modelos mentales soterrados y encriptados, como certezas o nociones incuestionables. Todo esto da lugar a un fallido intento de incursión en los terrenos del avance en cuestiones de género mientras que en el fondo no pueden -o no saben o no quieren- deshacerse de esta contaminación que pretende al fin y al cabo, que todo vuelva a una fijeza, un status quo sustancial para buscar en definitiva, una tranquilidad en los espacios de la consciencia que impida o incluso desmerezca el cambio.

En el último capítulo de la serie Juego de Tronos se termina de cerrar una historia y junto con esto un mensaje: La cancelación de la heroína. La obliteración de una posibilidad. Un vaciamiento conceptual.

En cierto sentido existió una ejecución. A traición y bajo bandera falsa, en arremetida oportunista, desteñida y confiscatoria del poder, un anodino y lavado Jon Snow, víctima de sus propias indefiniciones apuñala a su amada y reina al canto de la frase "Siempre serás mi reina", un oxímoron de humor negro para quien luego de ocho temporadas y cientos de acciones heroicas y nobles se convierte en diez segundos en asesino, parricida y regicida. Sin embargo lo insidioso y acaso perverso del acto de matar a cuchillo mientras se expresa amor incondicional no es solo el aniquilamiento físico, es decir la muerte real sino el asesinato conceptual. La metáfora no precisa de explicación pues casi ya no lo es, pues en el acto de doble transposición de sentido, su intento equilibrador no solo no repara, ni cuida, ni deja florecer esperanza alguna sino que estigmatiza para siempre la vocación de poder cuando se trata de una mujer.

El personaje de Khalessi (Daenerys Targaryen - Dany - Madre de dragones, etc.) no fue solo asesinado para evitar el desastre de la emoción en llamas sobre un dragón incontenible sino que fue debidamente moralizada en el sentido que le da Rita Segato de "que es la posesión masculina como dueña, como necesariamente potente, como dueño de la vida." en el sentido más violento, desde el lugar más innombrable de los acuerdos del pensamiento patriarcal: la pusieron en su lugar. Y con ello a todas las aspirantes a reinas. Para ello han reflotado todas las argumentaciones del abuso y la violación: ella se lo buscó.

La academia paternae del inconsciente colectivo sentenció a Khalessi hace mucho tiempo. $\mathrm{Su}$ final estaba plantado como pruebas falsas de policías corruptos por los showrunners y solo hizo falta el gatillo necesario que pide la narrativa para desencadenar un horror que justificara su sentencia.

Pensemos un momento lo que significa que Sansa se haya quedado como reina del Norte en Invernalia. Sansa es fría, y gobernará un territorio helado al que nadie quiere ir y que de hecho solo había sido conquistado por otros norteños (los Bolton) ya que en definitiva, es una tierra de poco valor. Ella sí logra coronarse y desde un alma gélida, gobierna como siempre quiso: manipulando a otros, tejiendo lazos complejos y conspirando, es 
decir, reproduciendo la forma en que las mujeres son vistas a través de la ventana cultural. Khalessi no fue ajusticiada, fue sacrificada. Un sacrificio religioso ritual de vieja escuela: el puñal directo al corazón a la vez que se pronuncian palabras piadosas y amorosas. Ejecutada por un "elegido", hombre (sacerdote habilitado) casi siempre, alguien en apariencia neutro como se supone lo justo y recto, alguien que no solo mata por enojo o pasión sino que entiende lo sacrificial como necesario, impersonal, que es en definitiva la mano ejecutora de un acto colectivo, la singularización, una persona de un pensamiento de agenda en el espacio y tiempo de una lección al mundo.

Así como la Inquisición, la crueldad se encuentra en su marco desensibilizante, en donde el dolor cura y la muerte redime. Mientras se quemaban mujeres por brujas en las hogueras, se leían fragmentos de la Biblia en actitud piadosa. Y no hay cinismo explícito aquí más que la confirmación de que el pensamiento subyacente es el de un ordenamiento determinado y determinista. En ese ordo no hay lugar para sentimientos, arrepentimientos ni dudas; es el espacio que la corporación moralizante y educativa utiliza para cercenar aquello que la contraviene, el de un aparente bien común, la epidermis del poder que no acepta ni siquiera ser rozada con una pluma y mucho menos con fuego. Y si el fuego del dragón fue una represalia en parte por la muerte de su mejor amiga (Missandei) fue también otra mujer la que inició aquel caos: Cersei, la reina cruel y malvada, sedienta tan solo de poder, que antes la manda a ejecutar. ¿Para qué? Para provocar la ira de la Reina de Dragones. Al fin de cuentas toda esta matanza queda reducida a una escaramuza entre vecinas, cosas de mujeres en el prejuicio y modelización de la mirada, como en una novela de la tarde.

Es interesante señalar como impacta aquí el ejercicio de la sexualidad, Dani se enamora, goza y disfruta, lo relata y comparte; ama a Khal Drogo y a Jon Snow, se acuesta con ellos, es pasional, ardiente, vital. El colectivo homo patriarcalis la ha rotulado: es una puta y como tal no merece gobernar, es dudosa, una mujer que goza y lo expresa merece el escarnio, la sospecha permanente y al final, el castigo.

Sansa en cambio ha debido soportar la insatisfacción y la frialdad. El no ser mujer plena como garantizador de capacidad de gobierno, la supresión del amor y la afectividad puesta en "la familia" en "el deber" en "los ideales". Una candidata perfecta, esconde sus emociones y necesidades, desea el poder como suplemento del placer y actúa direccionando sus energías a la conquista, como lo hace el varón, y por ello es confiable. Khalessi en cambio padece la mirada externa, la libertad que ejerce provoca rechazo, distancia y recelo y aún quienes la siguen fanatizados y devotos, lo hacen desde la pulsión más básica de la atracción y el miedo, es decir todo aquello que es incontrolable. Ella es incontrolable. El veredicto es que debe morir. Y en esa muerte está el vaciamiento continuo y para nada inocente de la identidad de la mujer libertadora, la cancelación arbitraria de una cuña en la narrativa y en los estereotipos bajo el paraguas del prejuicio respecto del accionar de la emoción desbordada y su asimilación con la locura.

Daenerys Targaryen es rifada y tirada a los leones de la cultura para ser devorada por las masas y diluida en el sistema. Si una reina que pretende liberar un pueblo tiene poder (y peor aún si su varón amante la desprecia) ésta, de inmediato, ipso facto sale a masacrar ciudadanos inocentes. De idealista determinada a asesina de masas en solo un instante de enojo. La transformación absurda, llena de clichés y altamente sesgada por una visión 
de estereotipo confirma lo insidioso del pensamiento que sirve de abono a estas ideas. La bajada conceptual puede leerse como la mujer independiente con poder es peligrosa, lo cual como todo sofisma, parece ser verdad. Lo cierto es que cualquier ser con el suficiente poder es potencialmente peligroso, sea mujer, hombre, dios o extraterrestre. Haber convertido a quien fuera una liberadora de cadenas y esperanza del mundo en una reina oscura, vengativa y cegada por mesianismo no debería analizarse fuera del contexto de un mundo en donde cierto pensamiento del mundo masculinizante decide, planifica, argumenta y demoniza según una postura de verdad racional auto referente.

Daenerys (y la promesa de un nuevo arquetipo) fueron entregados al mismo fuego que su dragón soltaba por la boca. Fue sacrificada en el altar del pensamiento arcaico y expuesta, su muerte como escarnio y advertencia para la posteridad.

La heroína en potencia devenida en reina cruel y asesina de masas es castigada (por un hombre que ejerce de suerte de justicia autoproclamada) con la muerte. Aleccionador acto de aparente necesidad, que además ha sido previamente consensuado bajo el pretexto de evitar un mal mayor.

Para el estudio y la formulación de un camino de la heroína habrá que remover entonces las capas resquebrajadas del imperio del pensamiento, el marco conceptual que autoriza la muerte de "locas incontrolables" en el sentido más inquisidor y bajo la apariencia de necesidad.

No habrá que tener entonces pudor en decirlo, el acto final de Jon es un feminicidio. A su vez un parricidio (es su tía), un regicidio (es su reina) y un acto cobarde y a traición. ¿Qué le hubiese pasado a Daenerys, Cersei, Olenna o Sansa si la situación hubiese sido inversa? Es previsible: la total y absoluta indignación.

Por supuesto que los personajes no existen, aunque nos encante vivirlos como reales. Son sus autores (y a través de ellos la sociedad toda) quienes hablan por ellos y ellos a su vez apéndices de una cultura que es también la representación de una escala de valores y ponderaciones. El sistema necesitó que la heroína no fuera tal. Que fuera un fiasco, una falsedad conceptual, una ilusión desechable. Mataron la esperanza, el candor y nos urgieron a que todo siguiera igual. Un triste final para una esperanza revitalizante. Quizás es cierto que no se deban esperar salvaciones mesiánicas, y también es verdad que la esperanza vana alimenta los fantasmas del poder entre las sombras que encarnan un ideal deseado, pero si nos han querido aleccionar, la advertencia se volvió una estigmatización y la alerta un despojo de la posibilidad de un nuevo arquetipo.

En la serie Vis a Vis, cuyo eje narrativo es alrededor de un grupo de reclusas en un presidiario privado para mujeres (2015, Netflix Alex Pina, Daniel Ecija) puede verse una serie de arquetipos estructurados como personajes que navegan sus circunstancias vitales dentro del dinamismo hostil de ese entorno de encierro. Como todo producto audiovisual destinado a entretener contiene todos los elementos necesarios para el paladar popular. Sexo, violencia, drogas, crueldad, venganza, asesinatos, traiciones y desgracias y en menor medida, algunas dosis de lealtad y ternura. Sin embargo y a pesar de ello, la lectura que puede extraerse a través del análisis de los personajes y de las escenas que viven, no es la simple estructura de una narración comercial sino un sustrato de conflictividad en un mundo donde heroínas y villanas mutan su papel de forma alternativa. Quien hoy es la posible heroína de una situación, al rato presenta un comportamiento deleznable 
y justo cuando se está a punto de odiarla vuelve a mostrar rastros de ternura o lealtad que la redimen, por lo general hasta su próxima caída. Es que en ese universo, buenos y malos son categorías móviles, blandas, intercambiables. Así como suele suceder en la vida, los móviles y las necesidades humanas son mutables e inestables. En este mundo de convivencia femenina la heroicidad se adscribe en primer lugar a la supervivencia. Y como esto es de extrema complejidad en ese mundo, las conductas, decisiones y lealtades solo pueden ser consideradas dentro de la misma. Así entonces uno de los personajes principales es conocido como "La Reina Mora", una criminal cuya característica principal es su capacidad de tramar planes de largo alcance. Incluso si muchos de ellos fracasan o no se cumplen del todo, siempre encuentra una forma de extraer alguna ventaja dentro del complicado y áspero mundo de la prisión. Zulema (así su nombre de ficción) (interpretado por Najwa Nimri) es inteligente, artera, sagaz, a veces en extremo leal y otras veces traicionera, tiene gestos nobles y otros abominables, mata, tortura, roba y salva. Escapa y la agarran. Tanto casi mata a su única mejor amiga como le deja dos millones de euros a la hija. Abandona a sus amigas y hace nuevos pactos solo para traicionarlos una y otra vez a unos y a otros. Es carismática, puede ser sensual, es agresiva, filósofa, amante de la música clásica, codiciosa y vengativa. Ama mostrar su poder mientras sabe cuándo pasar por débil. Se jacta de ser una superviviente y no duda en mandar a matar con la mejor de las sonrisas. Es, a efectos de la narrativa, un personaje perfecto. Pero no es la única, el personaje de Macarena una sencilla muchacha encerrada por un crimen que no cometió que a lo largo de la serie se convierte en una mujer temible y violenta. Sarai, la gitana y tantas otras componen una serie de heroínas de la supervivencia con todas las contradicciones que la vida impone.

De hecho vivir es una contradicción. Pues para mantener la vida hay que matar. Directa o indirectamente a los animales y plantas de los que nos alimentamos. Por acción directa o intermediación paga, matamos para vivir. Y en las extremas condiciones de la prisión, esto no hace más que agudizarse. La heroicidad en este caso está mucho más relacionado al imperativo de vivir que a alguna causa noble de orden abstracto y sin embargo -y aún con sus miserias- estos personajes encarnan rasgos de lo heroico. Pues en el camino de la heroína existen así como en el del héroe, muchas y muy variadas elecciones. Pero el punto central que diferencia en este caso a uno de otro es, entre tantos otros, es el de la carencia de un ideal abstracto, salvo el de la libertad. Pero incluso ésta se corresponde a una bien concreta. No se trata de ideas visionarias sino de la simple y pura oportunidad de escapar, de salir, de ser libre en forma real.

Pero ellas también son presas de sus emociones, sus pasiones, sus decisiones y en especial de las espesuras de sus temperamentos. Es particularmente notorio el final de la serie. Puede observarse una forma moderna de ritualidad cercana a algunas prácticas en las antiguas culturas como la celta y en algunas prehispánicas.

Analizar esto permitirá una deconstrucción simbólica de la metáfora implícita como motor dominante de una fuerza femenina en acción. Lo explícito es la historia, las acciones, los resortes narrativos que desencadenan una serie de sucesos de alto valor dramático y de una hondura psíquica y espiritual de corte femenino raramente visto en los formatos televisivos. Una presa llamada Soledad, de cierta edad y con muchos años como reclusa por haber asesinado a su marido, lleva a la vez dos cargas que actúan como un cerrojo sobre su 
endeble capacidad psíquica. Ella sufre de Alzheimer y por momentos realiza acciones que no puede recordar al rato. Su memoria se va perdiendo irremediablemente y esto la hace sufrir ya que cuando se da cuenta, su mundo interior colapsa. Por otro lado es acusada injustamente de conspirar para matar a un segundo marido, el cual ha conocido en forma reciente estando ella en prisión. La extraña forma en que sucede aquel primer encuentro se puede resumir en que Soledad, estando excedida de peso y con serios problemas cardíacos, recibe un corazón donado y se le practica un trasplante que resulta exitoso. Primera metáfora a incluir en el análisis es que el personaje de Soledad se caracteriza por tener lo que suele llamarse "un buen corazón", aspecto de su ser que se caracteriza por la bondad y un intento permanente por poner paz y armonía en su ya caótico entorno. Soledad recibe un corazón y su donante fallecida ha dejado un esposo ahora viudo. Queriendo agradecer a su deudo, Soledad lo convoca en un "vis a vis" en la cárcel y se enamoran y se casan. Por motivos de poder interno otra reclusa que necesita asegurar una posición económica manda a matar al hombre que en su testamento había dejado a su nueva mujer (Soledad) como única heredera a despecho de sus dos hijas que la han ido a incriminar como asesina a distancia. La policía investiga y todas las pruebas conducen a Soledad, que además de ser inocente está ya con su enfermedad avanzada. Por este motivo el director del penal -un psiquiatra sádico, abusador y con fuertes rasgos psicopáticos- ordena que se la interne en un psiquiátrico.

En medio de esto, Soledad les pide a sus amigas de la prisión que no la dejen llegar a ese punto de falta de dignidad y olvido. Concretamente les hace jurar que la matarán antes de llegar a eso. Entre otras tantas circunstancias se genera una gran revuelta, un motín al grito de "Sole no se va" y este es ferozmente reprimido por los guardias con un claro exceso del uso de la fuerza lo cual desencadena una batalla campal, un guardia muerto, heridos y un caos general.

Una reclusa consigue una pistola de un policía y las presas toman el presidiario. Suceden muchas cosas con varias líneas narrativas en paralelo pero en medio de esto Soledad se va al mando central y micrófono en mano se despide de todas agradeciendo entre lágrimas lo que éstas han hecho y agrega “-Yo me iré”. La próxima escena remarca el centro nodal de lo que aquí se está tratando que no es otra cosa que formas alternas de conceptualizar un posible Camino de la Heroína, aunque en este caso quizás debería llamarse "El Camino de las Heroínas" o mejor aún "Los caminos de las Heroínas".

En medio del pandemónium un grupo reducido de las mujeres, que son las más íntimas de Soledad se van con ella a una cama. En el grupo hay una yonqui con una adicción a la heroína y una experiencia por lo tanto en la inyección de sustancia. Ella la inyecta. Todas las demás la están tocando, a sus pies, acariciándole la mano y la cabeza. Están con ella brindando amor. Sarai, la más audaz para estos casos, toma una almohada y con todo el amor y el respeto posible, la ahoga hasta que muere. Todas lloran. El momento es de hondo dramatismo pero a su vez de profunda comunión. Las amigas la han liberado de la única forma en que podían hacerlo. El círculo desprolijo y cálido a su alrededor fue su último abrazo. Luego de eso es llevada al centro del patio y puesta sobre una pira al estilo de los antiguos rituales vikingos de cremación. Afuera los comandos de la policía ingresan con armas largas y cascos, rayos láser y violencia. Cuando llegan al lugar, en lugar de encontrar oposición se encuentran con todas las mujeres (muchas de ellas enemigas jura- 
das) todas unidas en el acto de despedida silenciosa de la "hermana presidiaria". Un ritual de purificación común, una ceremonia sin sacerdocio en medio de un campo hostil.

Esto es ficción. Se trata de un producto comercial, una serie episódica para ser vendida en Netflix. Pero es justamente por ello que su valor se vuelve doble. Este relato ha sido posibilitado como contraparte necesaria a una cultura de la violencia individualista recién a partir de los procesos de cambio que se están viviendo en el mundo en el campo de igualdad de género y diversidad. Pero no solo es sintomático como ejemplo narrativo, sino que cumple además con introyectar ideas del campo de la antropología para éstos temas (ver los escritos de Rita Segato) y de otras disciplinas que han desarmado la trama de la trampa del pensamiento patriarcal único. Así la posibilidad de que una conducta heroica implique la pérdida, el renunciamiento, la entrega y muy en especial el trabajo colectivo se vuelve un faro destellante en medio de historias que refieren a salvadores únicos, superdotados y esclarecidos. Aquí todas pierden y a la vez todas se liberan. El campo de la igualdad no está ya solo como oportunidades frente a la vida y la sociedad, sino en lo más abstracto y concreto que existe: la muerte. El sentido último ya no es la indicación de una solución, un mensaje, un destino o una idea, sino la expresión de la mancomunidad solidaria ante el deseo y la necesidad. Algo tan vital que conduce a la muerte y a la vez tan al borde del peligro que revitaliza las energías del psiquismo colectivo de ese grupo de mujeres. Ellas han hecho lo improbable y a sabiendas de que el resultado final luego de la ceremonia sería el castigo y la cárcel con penas agravadas. Nadie se adjudicó un triunfo ni festejó una victoria. El resultado posterior era por todos sabido. Sin embargo, luego de eso, se lograron cambios en la prisión. Y eso sí fue una ganancia residual. El sustrato que se había formado como eje formador del entretejido de aquella sociedad precaria, prevaleció como cuerpo de contención para una mejor convivencia y el advenimiento de nuevas reglas, un tanto más ecuánimes.

En la versión 2020 de She-Ra la princesa guerrera se puede observar como se han cambiado los modelos tanto desde el diseño como en la función dentro del relato. Este producto producido por DreamWorks Animation (2018, 52 episodios en 5 temporadas, dirigido por Noelle Steveson) contempla ya un amplio abanico de personajes femeninos en sus múltiples posibilidades. La misma She-Ra que en la versión de los años ochenta era una princesa guerrera estereotipada como un top model con espada, (incluso cuando el producto era para niñas). En esta reversión es una adolescente frágil y fuerte, indecisa y determinada, segura y dudosa. Adora, tal su nombre cuando no se ha convertido en She-Ra, encuentra que es la elegida para portar la espada mágica y salvar a Etheria, el reino en el que vive y que comparte con todo un mundo de princesas de carácter mágico cuyos reinos están siendo hostigados por el malvado Hordak. Su personalidad formada por profundas contradicciones la hacen en alguna medida profundamente humana. Y mucho más real aunque se trate de un relato fantástico con espadas mágicas y caballos voladores. She-Ra no está sola. Y de hecho a pesar de ser la protagonista (es el nombre de la serie animada) sus otras compañeras de aventuras tienen la misma relevancia, el mismo recorrido dramático en el arco de transformación de los personajes, una diversidad y profundidad en sus características y la posibilidad cierta de tener su propio espacio en la historia.

Y he aquí uno de los rasgos sobresalientes y notorios dentro del campo de relatos que refieren a sujetos especiales sean héroes o heroínas y éste es la íntima relación de la mi- 
sión con los vínculos. Sin bien la lealtad ha sido uno de los valores reinantes en el campo narrativo del héroe masculino, esta virtud se refiere en general a un acompañamiento, una ayuda, un aporte lateral con contingente mientras que en las historias que han comenzado a asomar el valor del vínculo supera incluso esta idea para dar espacio al sentido comunitario, social y de conexión de la heroína con el otros seres. La vincularidad no es un aditivo sino una razón de ser. En la medida que She-Ra logra acrecentar, crear, confiar y reconciliar caracteres y personalidades logra que en su misión heroica llegue a buen puerto. Es que el contacto, la interrelación, la cercanía emocional constituyen en este esquema un poder en sí mismo.

En la serie El príncipe dragón, producida por Wonderstorm y escrita por Aaron Ehasz y Justin Richmond para Netflix.

La primera temporada se estrenó el 14 de septiembre de 2018 con 9 episodios bajo el título de "Libro 1: Luna", el 15 de febrero de 2019 bajo el título de "Libro 2: Cielo" se estrenó la segunda temporada contando de nuevo con otros 9 episodios, y el 22 noviembre de 2019 se estrenó la tercera temporada, "Libro 3: Sol", que consta nuevamente de 9 episodios.

El personaje de la elfa de la luna llamada Rayla es fuerte, ágil, decidida, tierna, suave, tremenda luchadora, criteriosa, mágica y emocional. Su presencia en la serie marca una tendencia progresiva en la industria audiovisual y narrativa a los personajes complejos, multifacéticos, de capas superpuestas, altamente dotadas de habilidades extremas y de un rango de sensibilidad muy amplio. Podría parecer que esta descripción no tuviese nada de excepcional si no fuera porque en términos de producto audiovisual de la industria, este tipo de atributos o características no eran ni remotamente posibles poco tiempo atrás. La posibilidad de que un personaje central femenino sea más hábil y fuerte que su compañero varón de aventuras, que sea más criteriosa y a la vez profundamente emocional y que todo esto no melle su accionar y -aquí lo más importante- no requiera ser salvada por un varón, es de por sí, un avance que no nace sino de los cambios paradigmáticos que se vienen sucediendo en los terrenos de género y diversidad y que incluyen también otras luchas paralelas que otros campos sociales vienen llevando a cabo como las cuestiones raciales y de la etnicidad junto al concepto de extranjerización y pertenencia. Rayla es una elfa de la luna, tiene dos cuernos, cuatro dedos en cada mano y pie, orejas puntiagudas y vive en el mundo mágico de Xadia (el reino de los elfos).

El proceso de la construcción o des encriptación del Camino de la Heroína será incierto, fractal, multidinámico, contradictorio, vital y fértil pero es necesario. A la vez inevitable. En las márgenes del río de la historia real o ficcionada habrá más mártires, mujeres disruptivas, maleducadas, amantes y pasionales, malentendidas y hasta odiadas y será en aras del desmantelamiento de la cultura de la culpabilización que futuras generaciones encarnen ideales que, como todo en la Naturaleza, son impredecibles.

En la serie de Netflix: La casa de papel, al igual que lo ocurrido en Juego de Tronos con Khalessi, ocurre algo similar con otras características. Y esto no es raro, de hecho se trata de un modus operandi del sistema que lo exterioriza a través de los mensajes que lleva al mundo por medio de la cultura del entretenimiento. Se trata del final del personaje de Nairobi (Alba Flores).

Ella es aniquilada, ajusticiada. La mata un elemento de seguridad con rasgos psicopáticos, a sangre fría y sin necesidad real para sobrevivir. De hecho le servía más de escudo 
humano que como trofeo de guerra que es como el personaje lo narra "-Te dije que te mataría”. ¿Cuál era el sentido estratégico de su decisión? Si acordamos que como táctica de supervivencia de un militar entrenado no tiene ningún sentido, necesariamente se deberá concluir que el motivo profundo, oculto (incluso para sus autores) ha sido otro, mucho más profundo y riesgoso para el sistema patriarcal. Lo que éste más tema y detesta: se estaba convirtiendo en una líder que es la antesala de la heroína.

¿Se puede considerar casual que es Nairobi quien hacia el final de la temporada 1 habla a cámara y afirma “-Se viene el matriarcado"? Así, se ha cortado la planta venenosa de raíz. A Nairobi no la han matado, ha sido ajusticiada.

Es curiosa la semántica cuando nos presenta la literalidad de una idea a través de una sola palabra, y no es poco común que en el uso acostumbrado, su esencia (su verdadero, real y profundo significado) se nos pase de largo. Ajusticiar viene de hacer justicia. Y la justicia la administra el estado, es decir, el sistema. Ajusticiar significa no otra cosa que aplicar ciertos criterios de bien y mal para determinar si alguien debe vivir o morir.

Daenerys fue ajusticiada según las decisiones del concilio de los reyes y reinas de Westeros, Nairobi lo fue por un "loco" que representa sin lugar a dudas, a la así llamada "masculinidad tóxica" más recalcitrante (violento, machista, sádico, controlador).

Los personajes de índole psicopáticos forman un "club" que al sistema le viene perfecto para ser los autores de lo que éste no puede ejecutar sin quedar expuesto. Ante la muerte de Kennedy se le atribuyó el asesinato a un tal Lee Harvey Osvald. Haya existido realmente o no, el sistema cubrió sus huellas con la denominación de loco, enfermo, psicótico y otros, y esto hace cada vez que requiere un sicario que se ensucie las manos sin que pueda ser vinculado a ninguna organización, pública u oculta.

Pero veamos que dice Rita Segato al respecto de los crímenes así llamados "sexuales" que están emparentados con esto que podría denominarse "crímenes de deicidio femenino":

"Separo y diferencio así este tipo de crimen de toda explicación referida al deseo, al placer, a la sexualidad. Mi explicación no es libidinal, y si la inversión libidinal existe, ella está puesta en el pacto corporativo-mafioso, y no en el campo de la víctima sacrificial."

La idea de que este tipo de crímenes (en este caso en la narrativa de ficción) son personales, independientes y constreñidos a decisiones individuales es falsa. Los personajes no se representan a sí mismos sino a un colectivo de ideas. Por cada loco que asesina hay una idea que lo sustenta y es en ese mínimo espacio donde se dirime una cuestión de poder que no se deja ver fácilmente.

"Es por eso que la expresión "crímenes sexuales" es problemática, pues os lleva a una comprensión equivocada de lo que son crímenes perpetrados por medios sexuales. ¿Por qué? Porque por medio de la sujeción sexual se mata moralmente a la persona y a la sociedad que la cobija. El crimen sexual es un crimen profanador, capaz de destruir la confianza moral y de fragilizar a una sociedad entera. Esto es porque en el imaginario arcaico la moral social está muy anclada en la capacidad de custodia de los cuerpos de las mujeres por parte de sus 
tutores. Ese imaginario arcaico es muy difícil de desmontar. En el centro del mismo se encuentra el presupuesto de que las mujeres no somos enteramente persona, porque si por un lado sí lo somos, por el otros somos íconos, es decir, representantes de la integridad de nuestros pueblos y sus comunidades."

Así es que cuando se citan a ciertas heroínas del pasado, lo que se encuentra es un puñado de mujeres que han tomado las armas, realizado hazañas, proezas físicas y se han comportado según el ideario patriarcal, que es la conducta masculina clásica.

Una nueva visión que cree una ventana divergente en el espejo cultural que deshaga el endiosamiento que el héroe ha tenido a lo largo de la historia para intentar otra forma conceptual de humanidad a través de los ojos y la sensibilidad de lo natural encarnado por la mujer, pero no solo por ella.

Podría ser el entendimiento de una forma de energía, de idea, de concepto que invierta la lógica de la oposición por una más cercana a las que rigen los ciclos de la vida en donde la interdependencia es crucial para el equilibrio.

La heroicidad ha sido fundante en la cosmología occidental y en particular en su versión masculina. Cuando se exalta un rasgo se opaca otro y si existe un héroe hay alguien o muchos que requieren ser salvados, rescatados o aliviados. Las ideas heroicas implican un cierto mesianismo lo cual lleva implícito la necesidad de opresión. Sean los villanos de turno de una historia en particular, un fenómeno natural catastrófico o la tendencia a la entropía (es decir que ocurra lo más probable: guerras, desencuentros, enfrentamientos, y una larga lista de etcéteras), los héroes serían quienes se están encargados de restablecer un cierto orden. Cualquier novelista o guionista mediamente formado sabe que uno de los elementos que debe colocar en su narrativa es el o la antagonista, habitualmente némesis de quien protagonice la historia. Esto lleva a la naturalización de la idea de que para exista un héroe debe existir un villano. Ahora bien, ¿y si la idea entera está errada? ¿Es posible que exista una historia sin un verdadero enemigo? Quizás sí pero implicaría sin dudas que la noción de heroicidad debería mutar a otra clase de participación, más cerca del consenso y de la resolución armónica (incluso en unidades progresivas de conflicto explícito o de conflictividad latente) Podría ser que en ese caso la resolución del enigma no resida en una cuestión dilemática en la que se deba polarizar y elegir sino en un ordenamiento complementario, una espiral ascendente de sucesos que no debieran necesariamente colapsar ni implotar. Hay un espacio para la colaboración, la unión, el proceso nutritivo, la interacción coordinada, el movimiento balanceado junto a la espera, el abrazo, el calor y la posibilidad de crecimiento. Ese espacio, que es por naturaleza femenino, podría contener los fundamentos mismos para la necesidad de una heroicidad femenina no sujeta a las regulaciones del pensamiento patriarcal que ha marcado el camino del varón en cuanto a posible sujeto heroico. Pues el problema central reside en su cualidad de mandato, de introyección ordenadora de los valores que detenta una sociedad, un grupo, una religión o un imaginario sobre cuánto vale el hombre. Al fin y al cabo el varón vale lo que la sociedad dice que vale, es decir, su posible asignación de posibilidad heroica en un conjunto de posibilidades en un tiempo y un lugar. Para quien esto le resulte un pensamiento abstracto, cabe traer a colación que los demenciales sueldos que cobra un jugador de fútbol en algunos equipos no se condice con ninguna 
otra habilidad que la de su valor dentro de un esquema de juego con unas reglas determinadas. Y esa cuantificación del valor personal se da según una serie de variables que determina el mercado. Ni un médico, ni un investigador que esté buscando la solución a una pandemia ni un artista o pensador podrían cobrar jamás lo que gana un goleador de un equipo de primera de Italia o España por ejemplo. El valor de asignación no solo es simbólico, es eminentemente concreto. Se puede medir en millones de dólares o de cualquier moneda. Inútil es aquí plantear "quien vale más" puesto que lo que importa es entender que la validación es en definitiva social y como tal económica. El valor de un héroe está dado por su capacidad de aportar un beneficio a una sociedad en un momento particular de su historia. Y la aclaración de "particular" no es casual puesto que si un guerrero de la antigua Grecia corría con una espada para matar a un invasor, su función heroica su multiplicaba por cuanto atendía a una necesidad concreta. Imaginemos que esto sucediera en la sociedad actual contra una Uzi, ¿De qué le serviría sus años de prácticas de esgrima y lucha? Es casi irrisorio y sería causal de broma pensar en esto si no fuera porque a la hora de designar heroicidad (en especial la femenina), se continúa haciendo en base a premisas caducas, vencidas, alteradas o simplemente innecesarias. Así de groseras han sido las arbitrariedades con las que se ha sometido el rol femenino a lo largo de la historia a un lugar de no heroicidad o directamente de heroicidad innecesaria. Y es que ¿a dónde se debía llevar el poder? En primer lugar hacia la guerra, la conquista, el pillaje y el sometimiento. Cualquier poder contrario pareciera en este sentido más bien una debilidad. Cuidar, amamantar, acariciar, sonreír o callar simplemente no han sido considerados como valores, sino como simples acompañamientos, a veces necesarios pero nunca imprescindibles. ¿Quién entonces pagaría por ellos? La narrativa hizo lo que hizo el ser humano a lo largo de los tiempos y eso ha sido desatender toda manifestación de poder femenino y a veces incluso descalificarlo cuando no directamente censurarlo o en algunos momentos de la historia, demonizarlo. Si matar está bien (sean dragones, monos salvajes, enemigos horribles o extraterrestres) así entonces cuidar y empatizar está mal y en esta estructura polar del pensamiento se desdobla una condición superior e inferior, útil e inútil, caro y barato, vital o intrascendente, valorado o carente de sentido. Fue lógico entonces que muchas mujeres hayan expresado su idea de valor en los terrenos ya comentados. El problema ha sido y sigue siendo que estos terrenos, así como campos arrasados por los químicos, están además infectados de preconceptos, ideas e intereses que conspiran contra una verdadera fertilización del pensamiento y la acción, pero en especial, derrumban el valor de los procesos de la emoción y el sentimiento. Por ello no es raro que los héroes no lloren o rara vez lo hagan, la debilidad que pareciera sugerir los quitaría del lugar central de luchadores (nota: a los héroes se les está permitido llorar cuando triunfan, reciben un premio y son vitoreados por las masas, es decir, cuando son aprobados por la sociedad y el pensamiento dominante) Así el héroe llora de emoción luego de haber barrido con los monstruos, dominado a los salvajes, abatido a los enemigos y alcanzado la gloria. Entonces es un llanto heroico, pues la sociedad, la gente, el mundo y los dioses los han por fin aceptado en su panteón. Una vez más, esto no es una formulación abstracta de orden intelectual: un jugador de algún deporte popular cae al piso en un choque durante un encuentro y si acaso llorara, es visto como una debilidad y falta de temperamento casi imperdonable pero si mete un gol, ahí sí puede llorar, si enci- 
ma gana un torneo pues se puede deshacer en lágrimas. Pero no antes, no en el proceso, nunca en la dinámica de la vida, siempre en el reposo y luego de ganar o de perder... Es por ello que el valor asignado a una lágrima es de carácter inferior al de la rabia o la sangre pues no pareciera que sirva para ganar, matar o dominar. En el sistema de pensamiento patriarcal de Occidente, las lágrimas se las lleva el viento pero en cambio la sangre vertida pareciera glorificar la propia existencia. Y esto no deja de ser curioso puesto que si de derramar sangre se tratara, la mujer en promedio derrama mucho más sangre a lo largo de su vida que el varón.

Es por estas razones que no se cuestiona que el advenimiento de pensamientos alternativos sobre la necesidad de heroínas se ha vuelto tan complejo en los últimos tiempos. Hay quienes se conforman con feminizar un producto (cambios de roles que antes tenía un superhéroe por ejemplo y que lo protagonice una mujer) pero esto no es más que una acción burda del marketing del mundo del espectáculo y la mass media. El arco de situaciones y transformaciones propias del elemento femenino (independientemente de quien lo lleve a cabo) ha de tener sus propias características y esa construcción está aún en proceso.

Ese proceso es el que está en marcha. Ahora. En todo el mundo. Y avanza. Contendrá naturalmente su propia dinámica y también una serie de errores e inconsecuencias lógicas de un proceso en cambio permanente que se forma sobre la necesidad y no sobre una huella clara. Pero también esto es motivo de alegría y esperanza, ¿acaso es posible una perfección prefabricada? ¿Sería posible un advenimiento rupturista sin esto involucre dolor y pérdida? Así como el proceso del nacimiento, del útero a la vida y luego el también penoso proceso de crecimiento, los cambios y reformas en todos los niveles de la sociedad contendrán el germen de una nueva esperanza. Y esta no será solo para un colectivo, género o fragmento sino para la totalidad. No tiene un solo rostro, no hay líder ni gurú. Se abrirá paso a través de su horizontalidad, multiplicidad y diversidad. Y en los terrenos siempre fértiles de la narrativa ya se están dirimiendo las alternativas del futuro. En las series y películas, en los nuevos paradigmas de los personajes y las tramas y finalmente, en la propiciación de innumerables posibilidades para uno y mil caminos para muchas y diversas heroínas. Aquellas que luchan y las que curan, las que educan y las que amamantan, las que recuerdan y las que cuestionan, incluso quienes piensen que el nuevo mundo será uno en donde el concepto mismo de heroicidad individual será cosa del pasado. Bienvenidas todas y todos.

\section{Bibliografía}

Aristóteles, (siglo IV AC.) Poética.

Bordwell, D. (1985). La narración en el cine de ficción. Barcelona: Paidós.

Campbell, J. (1980). Los mitos en el tiempo. Buenos Aires: Emecé Editores.

Campbell J. (1959). El héroe de las mil caras, psicoanálisis del mito. México: Fondo de Cultura Económica (pp. 55, 62, 90, 99,107)

Campbell J. (19991). El poder del mito. Barcelona: Emecé (p. 38)

Eco, U. (1974). La Estructura Ausente. Barcelona: Lumen. 
Frazer, G. (1944). La Rama Dorada. Santa Fe de Bogotá: Fondo de Cultura Económica. García Márquez, Gabriel (1995). Como se escribe un cuento. Santa Fe de Bogotá: Voluntad. Graves, R. (2007). Los mitos griegos. Buenos Aires: Alianza Editorial.

Heindel, M. (1932). Misterios de las grandes óperas. Buenos Aires: Kier.

Jung, C.G. (1993). Encuentro con la Sombra (compilación). Buenos Aires: Kairós.

Jung, C.G. (1976). Psicología y Religión. Barcelona: Paidós.

Jung, C.G. (1964). El hombre y sus símbolos. Barcelona: Paidós.

Jung, C.G. (1951). AION Contribución a los simbolismos del sí mismo. Buenos Aires: Paidós.

Lieberman, Al. La Revolución del Marketing del Entretenimiento (UP)

May, R. (1993). Encuentro con la Sombra. Buenos Aires: Kairós

McKee, R. (1997). Story, el guión. Barcelona: Editorial Alba.

Niedner, H. (1986). Mitología Nórdica. Barcelona: Editorial Edicomunicación.

Segato R, (2016). La guerra contra las mujeres. Ed. Traficantes de Sueños

Segato R (2018) Contrapedagogías de la crueldad. Ed. Prometeo

Seger, L (1987). Como convertir un buen guión en un guión excelente. Buenos Aires: Editorial Rialp.

Tolkien J.R.R (1954). El señor de los anillos. Allen \& Unwin.

Velayos, T. (1995). George Lucas el poder de la fuerza. Barcelona: Royal Books.

Vogler C. (2005). El viaje del escritor. Madrid: Robin Book.

\section{Referencias bibliográficas}

Arendt H. (1963). Eichmann en Jerusalém

Capra F. (1983). El Tao de la Física Ed. Sirio (pp. 122, 216)

Klein N. (2020). Encuentro virtual publicado The guardian y otros

Murdock M. (2010) Yo, Mujer. Gaia Ediciones

Segato R. (2018) Contrapedagogías de la crueldad. Ed. Prometeo (pp. 15, 99).

From the deconstruction and reinterpretation of the heroic subject: The twilight of the patriarchal hero and the advent of the heroine. A holistic version of, complementary and inter-essential human heroicity

Heroism, as a concept and its symbolic value has been a central focus in many cultures. It was the narrative, in its various forms, that has enshrined heroicity in a myriad of stories, myths, and legends from oral fairy tales to transmedia.

Although heroic stories are found all over the world, it has been in the Western culture, where in the need of its own creation and expansion, there have been countless versions or heroes whose actions and feats have built the imagination of our civilization. 
Heroicity has a fundamental value in the way of thinking, feeling, and understanding the world and oneself within our culture, and strong individualism is its most recognizable trait.

The self-perception of the westerner is structured around saviors and chosen ones who make a difference in everyone's lives. This idea has a label, the mark of the dominant thought based upon an indisputable premise: God is male. He has a beard; he is strong, omnipotent and tends to get angry. He creates and punishes. And this axiomatic model was injected into the hero's ideals.

His basics attributes are strength, determination, courage, bravery and occasionally, intelligence.

It is not strange that God's human version, the hero, is somehow defined -despite his flaws and mistakes- by his heroic (divine) actions and in the vast majority of cases, as male. The hero, as proposed by the western culture, is almost always male. Becoming a hero -and being recognized as such- has been and still is a goal in itself. A point of arrival, a title, a reason for being both for the individual and for the society that produces, adopts, contains, and promotes it. The hero resonates in the minds of people and in their imagination, and, consequently, it is inscribed in history.

The hero immortalizes a fragment of his existence and for that, a, otherwise vulgar and ordinary human becomes a member of a select breed by extraordinary actions. He is, somehow, divine.

Thus, core values such as the ability to listen, to have empathy, to be tender, to be involved in dynamic interactions, to care about nature and countless others that are generally attributed to women, have been left out (almost in cultural secrecy). These values, which are more transcendental in life than in death, are not labeled as heroic in our society. In recent years (and due to the paradigm shift regarding the role of women and due to a very specific market demand), the movie and television industry has showcased a variety of heroic women. However, the harder the effort to unify the role under different circumstances, the more it has failed (with a few exceptions) under the temptation to build heroines deprived of essence and a raw copies of male heroes. A form of female heroism will undermine the darkest areas of the political model of the Western society and it existing bias: The patriarchal concept.

Thus, in the construction of female heroism, there will be an implicit contradiction with its preexisting notions. There is a conceptual abyss between creating live, nurturing, and caring relative to going out into the world to slaughter enemies

A female heroic form may end up in it not even being named that way unless the concept of a hero is also redefined. The advent of a heroine could create a semantic paradox. Perhaps its effective realization consists in fully undoing the idea that the hero (and the heroic) is necessary, ineffable and natural. Perhaps its mere enunciation can generate a disruptive gap in the system and this will be, in itself, an act of female heroism.

Keywords: Heroicity - transmedial - patriarchy - female - axiom. 


\section{Sobre a desconstrução e reinterpretação do sujeito heróico: o declínio do herói patriarcal e o advento da heroína.Uma visão holística, complementar e inter-essencial do heroísmo humano}

Resumo: A idéia do heroísmo e seu valor como símbolo tem sido central em muitas culturas. Foi a narrativa de várias maneiras que a consagrou em uma miríade de histórias, mitos e lendas. Das histórias orais à atual concepção transmedial.

Mas se histórias de heróis são encontradas em todo o mundo, foi no Ocidente que, na necessidade de sua criação e expansão, surgiram inúmeras versões de heróis cujas ações e façanhas construíram as imagens de nossa civilização.

A heroicidade é um valor fundamental da maneira de pensar, sentir, entender o mundo e a si mesmo na cultura. E sua marca mais reconhecível é o individualismo.

A autopercepção do ser ocidental está estruturada em torno de salvadores e enviados que fazem a diferença para todos. E tem um sinal, o selo do pensamento dominante baseado em uma premissa indiscutível: Deus é homem. Ele tem barba, é forte, onipotente e zangado. Crie e castigue. E esse modelo axiomático foi enxertado no ideal do herói. Suas características básicas são força, determinação, coragem, bravura, coragem e, ocasionalmente, inteligência.

Não é estranho que sua versão humana, com falhas e erros, mas divinizada por suas ações, seja, na esmagadora maioria dos casos, um homem. O herói que foi proposto pelo pensamento é quase sempre um homem.

Ser um herói -e ser reconhecido como tal- tem sido e é um objetivo em si, um ponto de chegada, um título, uma razão de ser. Tanto para o indivíduo quanto para a sociedade que o produz ou adota, o contém e promove. O herói ressoa na mente das pessoas, em seu imaginário e, como conseqüência, está inscrito na história. O herói imortaliza um fragmento de sua existência e, com ele, um humano vulgar e comum se torna, por suas ações, membro de uma casta seleta. É feito de uma maneira divina.

Como conseqüência, valores como capacidade de escuta, empatia, ternura, interação dinâmica e cuidado com a natureza e outros que geralmente são atribuídos às mulheres foram deixados de fora (quase em segredo cultural), e esses valores, que são eles estabelecem mais na vida do que na morte não oferecem em nossa sociedade a noção de heroísmo.

Nos últimos anos (e devido à mudança de paradigma em relação ao papel das mulheres e devido a uma demanda muito específica do mercado), o cinema e a televisão nos lançaram uma variedade de mulheres heróicas. No entanto, quanto mais se tenta unificar o papel sob diferentes fórmulas, mais se cai -com poucas exceções- na tentação de construir heroínas desprovidas de essência, cópias grosseiras do homem.

Uma forma de heroísmo feminino minará as áreas mais sombrias do modelo político da sociedade ocidental: o conceito patriarcal, uma vez que existe um viés.

$\mathrm{Na}$ construção de uma heroicidade feminina, haverá uma contradição implícita com as noções preexistentes de heroicidade, pois entre criar, nutrir e cuidar ou sair para o mundo para abater inimigos, existe um abismo conceitual. 
Uma forma heróica feminina pode terminar nela, nem mesmo sendo chamada dessa maneira. A menos que o conceito de herói também seja ressignificado. $O$ advento da heroína pode criar um paradoxo semântico. Talvez sua realização efetiva consista em desfazer completamente a idéia de que o heróico é necessário é inefável e natural. Talvez sua mera enunciação possa gerar uma lacuna disruptiva no sistema e isso por si só, um ato de heroísmo feminino.

Palavras-chave: Heroicidade - transmedial - patriarcado - feminino - axioma.

[Las traducciones de los abstracts fueron supervisadas por el autor de cada artículo] 